\title{
Review \\ Molecular Landscapes of Gastric Pre-Neoplastic and Pre-Invasive Lesions
}

\author{
Gianluca Businello ${ }^{1}$, Valentina Angerilli ${ }^{1}$, Paola Parente ${ }^{2} \mathbb{D}$, Stefano Realdon ${ }^{3}$, Edoardo Savarino ${ }^{4} \mathbb{D}$, \\ Fabio Farinati ${ }^{4}$, Federica Grillo ${ }^{5,6}{ }^{\mathbb{D}}$, Alessandro Vanoli ${ }^{7}$ (D), Francesca Galuppini ${ }^{1}$ (D), Silvia Paccagnella ${ }^{1}$, \\ Gianmaria Pennelli ${ }^{1}$, Luca Mastracci ${ }^{5,6}$, Luca Saragoni 8 (D) and Matteo Fassan ${ }^{1,3, *(\mathbb{D})}$
}

1 Surgical Pathology Unit, Department of Medicine (DIMED), University of Padua, 35121 Padua, Italy; glc.businello@gmail.com (G.B.); valentina.angerilli@gmail.com (V.A.); francesca.galuppini@unipd.it (F.G.); silviapak80@gmail.com (S.P.); gianmaria.pennelli@unipd.it (G.P.)

2 Pathology Unit, Fondazione IRCCS Ospedale Casa Sollievo della Sofferenza, 71013 San Giovanni Rotondo, Italy; paolaparente77@gmail.com

3 Veneto Institute of Oncology (IOV-IRCCS), 35128 Padua, Italy; stefano.realdon@iov.veneto.it

4 Division of Gastroenterology, Department of Surgery, Oncology and Gastroenterology, University of Padua, 35121 Padua, Italy; edoardo.savarino@unipd.it (E.S.); fabio.farinati@unipd.it (F.F.)

5 Anatomic Pathology Unit, Department of Surgical Sciences and Integrated Diagnostics (DICS), University of Genova, 16132 Genova, Italy; federica.grillo@unige.it (F.G.); luca.mastracci@unige.it (L.M.)

6 Ospedale Policlinico San Martino, IRCCS for Oncology and Neuroscience, 16132 Genova, Italy

7 Anatomic Pathology Unit, Department of Molecular Medicine, University of Pavia and Fondazione IRCCS San Matteo Hospital, 27100 Pavia, Italy; alessandro.vanoli@unipv.it

8 UO Anatomia Patologica, Ospedale G.B. Morgagni-L. Pierantoni, 47121 Forlì, Italy; luca.saragoni@auslromagna.it

check for updates

Citation: Businello, G.; Angerilli, V.; Parente, P.; Realdon, S.; Savarino, E.; Farinati, F.; Grillo, F.; Vanoli, A.; Galuppini, F.; Paccagnella, S.; et al. Molecular Landscapes of Gastric Pre-Neoplastic and Pre-Invasive Lesions. Int. J. Mol. Sci. 2021, 22, 9950. https://doi.org/10.3390/ ijms22189950

Academic Editor: Evgeny Imyanitov

Received: 21 July 2021

Accepted: 11 September 2021

Published: 14 September 2021

Publisher's Note: MDPI stays neutral with regard to jurisdictional claims in published maps and institutional affiliations.

Copyright: (c) 2021 by the authors. Licensee MDPI, Basel, Switzerland. This article is an open access article distributed under the terms and conditions of the Creative Commons Attribution (CC BY) license (https:// creativecommons.org/licenses/by/ $4.0 /)$.
* Correspondence: matteo.fassan@unipd.it; Tel.: +39-049-8211312

\begin{abstract}
Gastric carcinoma (GC) represents one of the most common and most lethal malignancies worldwide. The histopathological characterization of GC precursor lesions has provided great knowledge about gastric carcinogenesis, with the consequent introduction of effective strategies of primary and secondary prevention. In recent years, a large amount of data about the molecular events in GC development is emerging, flanking the histomorphological descriptions. In this review, we describe the landscape of molecular alterations in gastric pre-invasive lesions with a glance at their potential use in the diagnostic and therapeutic decision-making process.
\end{abstract}

Keywords: gastric carcinoma; pre-neoplastic lesions; gastric carcinogenesis; biomarkers; pathology

\section{Introduction}

\subsection{Epidemiology and Risk Factors}

According to the latest GLOBOCAN analysis [1], gastric cancer (GC) is the fifth most diagnosed carcinoma in both males and females, with more than 1 million new diagnoses in 2018. With about 800,000 deaths in 2018, GC also represents the third leading cause of cancer-related death worldwide. Both GC incidence and mortality present substantial differences among countries, with low/middle income areas accounting for more than $70 \%$ of cases. The highest GC incidence (up to 32 cases/100,000) is reported in Eastern and Western Asia, Eastern Europe and South America. Conversely, GC incidence in North America and Western Europe has continuously decreased during the last 50 years and is currently standing at less than 7 cases/100,000 [1]. Moreover, in Western countries, a progressive reduction of distal-arising GC has been observed. These trends probably reflect the effects of successful Helicobacter pylori $(\mathrm{Hp})$ eradication and improvement of hygiene standards [2]. On the other hand, a higher incidence of cardiac GC has been reported, probably related to increasing rates of gastroesophageal reflux disease and obesity [3]. GC is a multifactorial disease and both genetic and environmental factors are involved in gastric carcinogenesis. GC-associated risk factors include Hp and Epstein-Barr virus (EBV) 
infection, family history of GC, tobacco smoking, microbiome modifications induced by long-term use of proton-pump inhibitors and high consumption of salt-preserved/smoked foods and of red/processed meat together with low intake of fresh fruit/vegetables [4,5]. In particular, $\mathrm{Hp}$ is the environmental factor carrying the greatest weight worldwide, as it is associated not only with GC but also with gastric mucosa-associated lymphoid tissue (MALT) lymphoma [6]. Hp also has a synergistic effect with other risk factors [7]. Inherited GC risk factors are best exemplified by hereditary syndromes with mutations in genes involved in molecular pathways of gastric carcinogenesis. Major syndromes associated with GC are hereditary diffuse gastric cancer (HDGC; mutations in CDH1), gastric adenocarcinoma, proximal polyposis of the stomach (GAPPS; YYP1 binding motif of APC) and familial intestinal gastric cancer (FIGC) [4,8]. Patients with familial adenomatous polyposis (FAP; APC), Peutz-Jeghers syndrome (STK11), Li-Fraumeni syndrome (TP53) or Lynch syndrome (particularly with MLH1 or MSH2 mutations), also have an increased risk of developing GC [9]. Hereditary GCs, related to both cancer susceptibility syndromes and/or other genetic causes, account approximately for $1-3 \%$ of cases, and a detailed discussion of these conditions is far beyond the aim of this review [10,11]. Polymorphisms in genes codifying for IL-1beta, TNF-gamma and IL-10 are other GC-related host-dependent genetic factors [12]. GC-related precancerous conditions are chronic atrophic/metaplastic gastritis (AG), pernicious anemia, peptic ulcer disease, previous gastric surgery and Ménétrier's disease $[4,9]$.

\subsection{Histological and Molecular Classifications of GC}

GC is a molecularly and phenotypically heterogeneous disease. Over the years, numerous morphologic and molecular classifications have been proposed in order to dissect the complexity of this disease. Despite these efforts, a unifying classification of GC is still lacking [13].

The most common histotype of GC, gastric adenocarcinoma (GAC), accounts for more than $90 \%$ of GCs [14]. Squamous cell carcinoma, adenosquamous carcinoma, undifferentiated carcinoma, gastroblastoma and neuroendocrine neoplasms are well-described but considerably rarer gastric epithelial malignancies [14].

Two of the most widely accepted GAC classifications are the WHO and Laurén's classifications.

The 2019 WHO classification recognizes five main subtypes of GAC: (i) tubular adenocarcinoma, (ii) papillary adenocarcinoma, (iii) mucinous adenocarcinoma, (iv) poorly cohesive carcinoma (PCC) and (v) mixed adenocarcinoma. GAC with lymphoid stroma, hepatoid carcinoma, micropapillary carcinoma and GAC of fundic-gland type represent rarer variants of GAC [14].

Laurén's classification subdivides GAC into intestinal (53\%), diffuse (33\%) and indeterminate (14\%) types [15]. This classification is important not only from a historical point of view but also from a methodological one. As described below, studies that investigate molecular alterations in GC are usually based on this classification. Moreover, Laurén's two main types also present different biological characteristics: intestinal type GAC (IGAC) is usually sporadic and associated with Hp and Correa's cascade [9], while diffuse GAC carcinoma (DGC) is characterized by loss of E-cadherin expression [16].

Two NGS-analysis-based molecular classifications of GC are commonly recognized: the 2014 Cancer Genome Atlas (TCGA) and the 2015 Asian Cancer Research Group (ACRG) classifications. TCGA classification distinguishes four molecular subtypes of GAC: (i) tumors positive for Epstein-Barr virus (EBV) (9\%), (ii) microsatellite instabilityhigh (MSI) tumors (21\%), (iii) genomically stable (GS) tumors (20\%) and (iv) tumors with chromosomal instability (CIN) (50\%) [17]. According to ACRG results, GAC may be classified into four other subtypes: (i) microsatellite unstable (MSI) tumors (23\%), (ii) microsatellite stable with features of epithelial-mesenchymal transition (MSS/EMT) tumors (15\%), (iii) microsatellite stable with TP53 active (MSS/TP53+) tumors (26\%) and (iv) microsatellite stable with TP53 inactive (MSS/TP53-) tumors (36\%) [18]. 
The principal clinicopathological and molecular characteristics of TCGA and ACRG molecular subtypes are summarized in Tables 1 and 2.

Table 1. Principal molecular and clinicopathological features of TCGA molecular subtypes.

\begin{tabular}{|c|c|c|c|}
\hline \multicolumn{4}{|c|}{ TCGA } \\
\hline CIN (50\%) & EBV $(9 \%)$ & MSI (21\%) & GS (20\%) \\
\hline $\begin{array}{l}\text { GEJ/cardia } \\
\text { Intestinal type } \\
\text { DNA aneuploidy } \\
\text { Highly variable CIN } \\
\text { TP53 mutations } \\
\text { Amplification of TKR }\end{array}$ & $\begin{array}{l}\text { Male prevalence } \\
\text { Gastric corpus or fundus } \\
\text { Extensive DNA promoter } \\
\text { methylation } \\
C D K N 2 A \text { promoter } \\
\text { hypermethylation } \\
\text { PIK3CA, ARID1A and BCOR } \\
\text { mutations }\end{array}$ & $\begin{array}{l}\text { Elderly age } \\
\text { Gastric antrum } \\
\text { Intestinal type } \\
\text { Best prognosis among TCGA } \\
\text { subtypes } \\
\text { MLH1 promoter } \\
\text { hypermethylation } \\
\text { High mutational burden } \\
\text { Possibly associated with } \\
\text { Lynch syndrome }\end{array}$ & $\begin{array}{l}\text { Younger age } \\
\text { Distal localization } \\
\text { Poorly cohesive histotype } \\
\text { Worst prognosis among TCGA } \\
\text { subtypes } \\
\text { Low CNAs and mutational burden } \\
\text { ARID1, RHOA and CDH1 } \\
\text { mutations } \\
\text { CLDN18-ARHGAP26 fusion in } 15 \%\end{array}$ \\
\hline
\end{tabular}

Table 2. Principal molecular and clinicopathological features of ACRG molecular subtypes.

\begin{tabular}{llll}
\hline \multicolumn{4}{c}{ ACRG } \\
\hline MSS/TP53- (36\%) & MSS/TP53+ (26\%) & MSI (23\%) & MMS/EMT (15\%) \\
\hline
\end{tabular}

Gastric antrum
Intestinal type
Early stage at diagnosis
Best prognosis among ACRG
subtypes
DNA methylation signature
Presence of hypermutation
Silencing of $M L H 1$
ARID1A, KRAS and ALK
mutations
PIK3-PTEN-mTOR pathway
dysregulation
PD-L1 overexpression

Male predominance Intestinal type EBV infection ARID1A, PIK3CA, SMAD4 and $A P C$ mutations
Male predominance Intestinal type RHOA mutations APC, ARID1A, KRAS, PIK3CA and $S M A D 4$ mutations Highest rate of TP53 and
Male prevalence
Younger age

Poorly cohesive histotype

Higher frequency of peritoneal spreading Worst prognosis among ACRG subtypes Loss of CDH1 expression

Molecular characterization of GC has provided valuable knowledge about the biology of this disease, permitting the development of targeted therapies (Table 3) [19].

Table 3. Principal and promising targeted and immunotherapies in advanced gastric cancer.

\begin{tabular}{ccc}
\hline MOLECULAR TARGET & THERAPEUTIC AGENT (Trial) & LINE OF THERAPY \\
HER2 & $\begin{array}{c}\text { Trastuzumab (ToGa [20]) } \\
\text { Trastuzumab deruxtecan } \\
\text { (DESTINY-Gastric 01 [21]) }\end{array}$ & $\begin{array}{c}\text { First line } \\
\text { Third or later line }\end{array}$ \\
\hline FGFR2 & Bemarituzumab (FIGHT [22,23]) & First line \\
\hline MET & $\begin{array}{c}\text { Onartuzumab (METGastric [24]) } \\
\text { Savolitinib (VIKTORY [25]) }\end{array}$ & Second line \\
\hline VEGF/VEGFR & $\begin{array}{c}\text { Ramucirumab (RAINBOW [26]) } \\
\text { (REGARD [27]) }\end{array}$ & $\begin{array}{c}\text { Second line } \\
\text { Second line }\end{array}$ \\
\hline CLAUDIN 18.2 & Zolbetuximab (FAST [28]) & First line \\
\hline PD-1/PD-L1 & Nivolumab (CHECKMATE-649 [29]) \\
& (ATTRACTION-4 [30]) & First line \\
First line
\end{tabular}




\section{Precursor Lesions of Intestinal Type Adenocarcinoma and Their Molecular Alterations}

In 1975, Pelayo Correa first proposed a stepwise model of gastric carcinogenesis, which has revolutionized the comprehension of IGAC pathogenesis, allowing the introduction of effective GC prevention measures [32]. The so-called Correa's cascade begins with the onset of chronic gastritis (ChG), possibly evolving into atrophic gastritis (i.e., loss of appropriate glands) [33] with the development of intestinal metaplasia (IM). Progressive acquisition of DNA mutations and molecular alterations leads to epithelial dysplasia. When neoplastic cells acquire the ability to invade the surrounding stroma, the final step of invasive carcinoma is reached (Figure 1) [34].
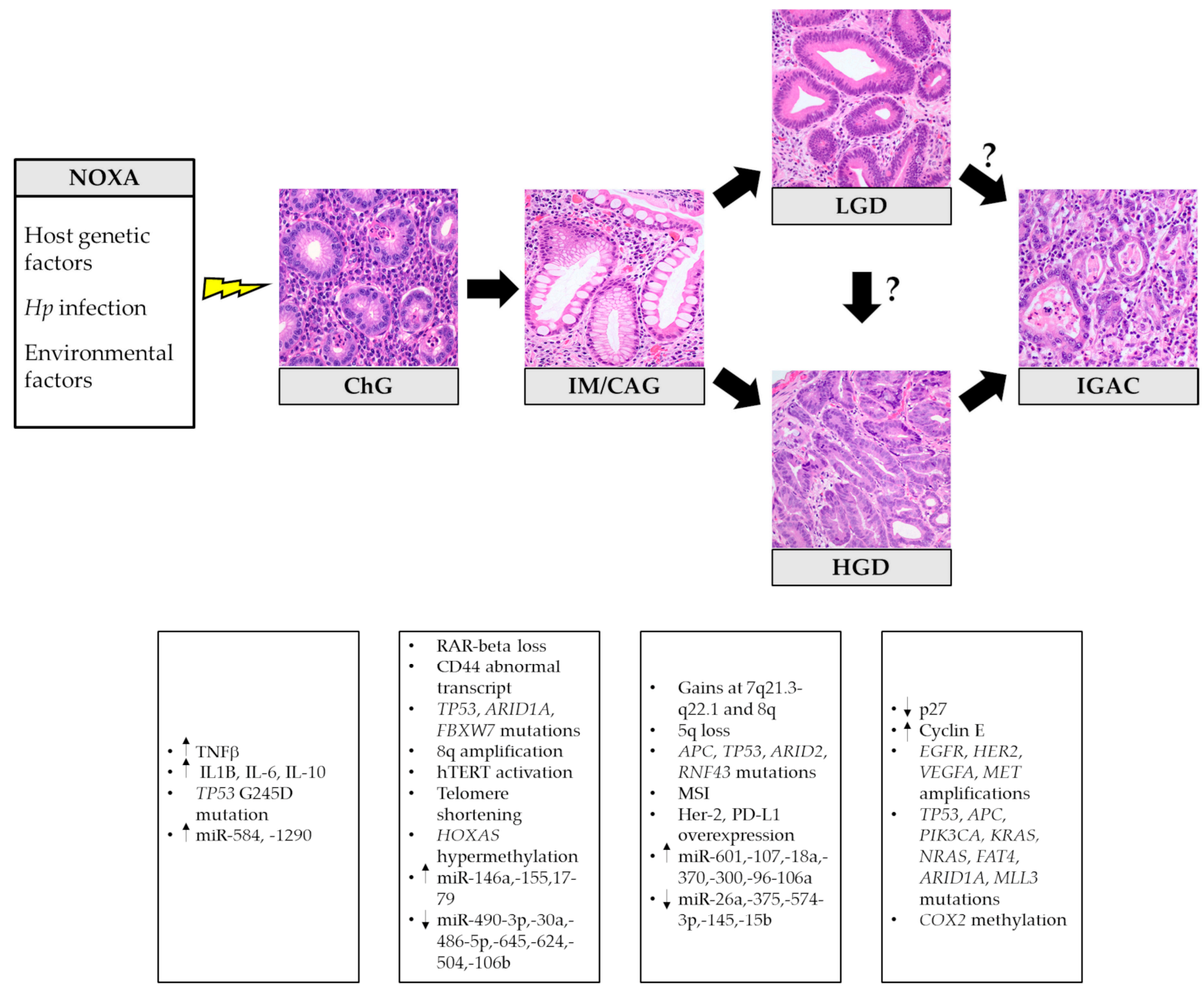

Figure 1. Histopathological stages and related principal molecular alterations in intestinal-type gastric cancer oncogenesis. Hp: Helicobacter pylori; ChG: chronic gastritis; IM/GAC: intestinal metaplasia/chronic atrophic gastritis; LGD: low-grade dysplasia; HGD: high-grade dysplasia; IGAC: intestinal-type gastric adenocarcinoma. The histological pictures were taken from routine diagnostic cases and have not been previously used for any other publication.

\subsection{Chronic and Atrophic Gastritis}

$\mathrm{Hp}$ is one of the main and most extensively studied etiological agents of ChG. Hp induces chronic gastric inflammation with atrophy, through the synthesis of molecules such as neutrophil myeloperoxidase-hypochlorite-hydrogen peroxide, macrophage nitric oxide and epithelial cell hydrogen peroxide. Consequent production of reactive nitrogen and oxygen species, lipid peroxidation, free radical formation and mutagens such as 8oxo-7,8-dihydro-2'-deoxyguanosine and 8-nitroguanine induces cellular, DNA and RNA damage $[35,36]$. Additionally, Hp's toxins (primarily CagA) interact with host proteins (e.g., ASPP2, RUNX3, PI3K, SHP2 and E-cadherin), leading to alterations in PI3K-AKT, 
Ras-ERK and Wnt pathways, inactivation of p53 and RUNX3, disruption of adherens junctions and deregulation of MGMT, MLH1 and CDKN2A [7,37].

Whole-exome sequencing and deep-sequencing analysis have shown the presence of somatic mutations in Hp-infected gastric samples, most notably non-synonymous lowabundance mutations in TP53 and ARID1A. In particular, TP53 G245D is the most frequent reported mutation in $\mathrm{Hp}$ gastritis [38]. Mutations in $\mathrm{Hp}$ gastritis are predominantly $\mathrm{C}: \mathrm{G}>\mathrm{T}: \mathrm{A}$ transitions in $\mathrm{GpCpX}$ sequences, which are a marker of activation-induced cytidine deaminase (AID) activity and a typical molecular signature of GC $[38,39]$. Moreover, CagA toxin also upregulates some microRNAs (miRNAs) such as miRNA-584 and miRNA-1290 [40].

Within the context of post-transcriptional regulation, several miRNAs and long noncoding RNAs (lcnRNAs) have been found to be differentially expressed in Hp-related $\mathrm{ChG}$, when compared to normal mucosa or GC [41-43]. For example, Hp-infection-related lncRNA AF147447 has been reported to act as a tumor suppressor and to be dysregulated during the multistep cascade of gastric carcinogenesis [44].

The final effects of these processes are cellular proliferation, DNA hypermethylation, loss of apoptotic capacity and epithelial-mesenchymal transition [7]. The acquisition of aforementioned molecular alterations is morphologically unveiled by the development of IM, low/high grade dysplasia and IGAC in the setting of Hp gastritis.

$\mathrm{Hp}$ is undoubtedly the major risk factor for GC. However, it is not the only microbial agent involved in gastric carcinogenesis. By performing 16S rRNA gene analysis, differences in microbial diversity and richness between GC and atrophic gastritis and IM were found, indicating the role of microbial dysbiosis, especially of oral bacteria, in gastric carcinogenesis $[45,46]$. Furthermore, specific clusters of oral bacteria were found to be depleted following Hp eradication in patients with persistent inflammation [47].

Because $\mathrm{Hp}$-induced inflammation is the most important mechanism of gastric carcinogenesis, the role of the immune microenvironment in GC progression is of great interest but is yet to be elucidated. Neutrophil density is positively correlated with gastric epithelium cell proliferation in gastritis, suggesting neutrophils might promote cell proliferation [48]. Furthermore, CCL5+ T cells, which are presumably activated cytotoxic $\mathrm{T}$ cells, together with neutrophils, seem to play an important role in the active inflammatory process of ChG [49].

Autoimmune gastritis (AIG) is another important cause of ChG. Despite being considered responsible for less than $5 \%$ of gastritis, AIG is often underdiagnosed, and its epidemiological burden is probably higher [50]. In AIG, the adaptive immune system selectively damages oxyntic cells, leading to corpus/fundus atrophy eventually with hypo- and achlorhydria. In the context of AIG, IM and spasmolytic polypeptide-expressing metaplasia (SPEM) may also develop. Following Correa's cascade, dysplasia and invasive carcinoma may subsequently occur. While the exact risk of GC in AIG is still undefined [50-52], some authors suggest that GC in AIG is mostly confined to patients with concomitant $\mathrm{Hp}$ infection [53]. It is worth remembering that AIG is also associated with an increased risk of neuroendocrine tumors (NETs). Oxyntic-atrophy-induced hypergastrinemia induces hyperplasia of enterochromaffin-like cells, which may progress to dysplasia and development of type I NETs [50].

In chronic gastritis, different cytokines (IL-8, TNF-alpha, IL-10, IL-1B, IL-1RA, IL-22, IL-23, IL-32, IL-33) seem to have a role in gastric carcinogenesis, tumor growth, metastatic potential and/or chemoresistance [54]. Moreover, IL-1beta has been reported to induce aberrant DNA methylation in a mouse model [55]. These observations suggest that GC risk may also be influenced by the type of cytokines produced by different clusters of $\mathrm{T}$ helper lymphocytes responding to $\mathrm{Hp}$ or $\mathrm{H}+/ \mathrm{K}+$ ATPase antigens.

\subsection{Intestinal Metaplasia and the "Point of No Return"}

IM is defined by the replacement of native gastric mucosa by an epithelium with intestinal commitment. IM is associated with an estimated GC risk of $0.13-0.25 \%$ per year [56]. Median time of progression to GC in patients with IM is reported to be 6.1 years [57]. Three 
main IM subtypes are recognized [58,59]. The most common is type I IM (complete or small intestinal type), characterized by mature enterocytes admixed with Paneth cells and sialomucins producing goblet cells, with a considerably decreased expression of gastric mucins (MUC1, MUC5AC and MUC6) in favor of intestinal mucin (MUC2). Type II (incomplete or immature, colonic type) presents neutral/acid sialomucins secreting columnar cells in various stages of differentiation and goblet cells usually secreting sialomucins, together with a lack of absorptive cells. Type III (incomplete) is defined by the presence of columnar cells secreting acid sulfomucins. Both type II and III express MUC1, MUC5AC and MUC6. Differences in commitment between complete and incomplete IM are also highlighted by the different expression of gastric (SOX2) and intestinal (CDX2) transcription factors: while CDX2 is expressed in all types of IM, SOX2 is negative in $93 \%$ of complete IM and positive in $85 \%$ of incomplete types [60]. Despite the fact that some authors [61-74] suggest that incomplete IM is associated with increased risk of GC, there is no conclusive evidence of differences in cancer progression among IM types, and IM characterization is not currently recommended in clinical practice [59].

A mutation rate of 2.6 mutation/Mb has been reported in IM. This value is higher than the normal gastric mucosa mutation rate $(0.4$ mutations $/ \mathrm{Mb})$ but lower than that reported in non-hypermutated GC (6.9 mutations/Mb) [65]. Metaplastic regions taken from the same patient seem to be genetically distinct and IM is probably a condition with high intra-patient multiclonality. Mutations in IM are frequently represented by $\mathrm{C}>\mathrm{T}$ transitions in $\mathrm{CpG}$ dinucleotides, a mutational signature that correlates with age at cancer diagnosis. $\mathrm{T}>\mathrm{G}$ transitions, a signature putatively associated with gastric acid, have also been described in IM [65]. TP53 and ARID1A are two of most frequently mutated genes in GC. Interestingly, in the series of Huang and colleagues [65], TP53 and ARID1A are reported to be mutated only in $2 \%$ and $3 \%$ of IM samples. Other authors describe p53 alterations and TP53 loss of heterozygosis, respectively in 30\% and 14\% of IM regions [66,67].

In the Huang series [65], FBXW7 is the only significantly mutated gene in IM identified by MutSigCV analysis. Despite being a driver gene, FBXW7 is mutated only in $4.7 \%$ of IM versus $9.2-18.5 \%$ of GC. Comparing these different values, it is clear that additional genomic alterations are needed for the development of GC [65]. Mutations of APC have also been reported in IM [59].

Somatic copy number alterations (sCNAs) have been described in $12.5 \%$ cases of IM, the most common being chromosome 8q (8q22.3-8q24.3) amplification [65]. Notably, this amplified locus also contains the MYC oncogene (8q24.21). IM presents shorter telomere length when compared to normal gastric mucosa. In particular, antral IM has shorter telomeres than corpus/cardiac IM [65]. An association between 8q amplification and telomere shortening has been suggested [65]. Interestingly, telomere length seems to be similar between GC and normal gastric mucosa, but advanced GC has longer telomeres than early GC $[65,68]$. Considering these results, it is possible to speculate that telomeres are initially eroded in IM and subsequently restored during progression to advanced GC.

DNA methylation levels are higher in IM than in mucosa with ChG [64]. Antral IM presents higher levels of DNA methylation than corpus/cardiac IM. Moreover, high levels of somatic mutations and sCNAs have been associated with highly methylated antral IM [65]. In contrast, global intragenic hypomethylation has not been detected in IM, representing a later event in Correa's cascade. Finally, Lin and colleagues [69] suggest that hypermethylation of HOXA5 has a role in the development of gastric cardiac IM.

Other molecular alterations occurring in IM are loss of RARbeta, production of CD44 abnormal transcripts and microsatellite instability [9]. Microsatellite instability has been documented in incomplete IM adjacent to MSI GC, suggesting that it may be an early event in gastric carcinogenesis [70].

IM seems to be related also to dysregulation in miRNAs' pathways. Levels of miRNA146a and miRNA-155 are higher in patients with Hp-induced IM than in healthy subjects [71]. According to Li and colleagues [72], the miRNA 17-92 cluster (i.e., miRNA-17-5p, $-17-3 p,-20 a,-18 a,-92 a,-19 a$ and $-19 b)$ is upregulated in IM and could be possibly used as a 
serum biomarker for early detection of IM and GC. Reported downregulated miRNAs in IM are miRNA-490-3p and miRNA-30a [73-75]. Deregulation of hsa-miRNA-486-5p, -645, $-624,-504$ and $-106 \mathrm{~b}$ has also been reported in IM [76].

Even though Correa's cascade is described as a linear process, gastric carcinogenesis appears to be rather more dynamic. Pre-neoplastic lesions can regress or evolve, and progression may even abruptly skip some theoretical stages. The efficacy of Hp eradication in inducing regression of $\mathrm{ChG} / \mathrm{AG}$ and in reducing the risk of GC progression is well documented [64]. The so-called "point of no return" represents a stage in gastric carcinogenesis in which $\mathrm{Hp}$ eradication leads to no substantial advantages in terms of histological regression and GC risk reduction. Different studies have suggested that the point of no return may be the IM stage [77-82]; however, regression of IM to ChG/ AG has also been reported $[62,83]$. Taken together, these results suggest that IM is a condition with low probability of regression after $\mathrm{Hp}$ eradication. The irreversible molecular alterations inducing the point of no return remain unknown.

Risk of GC progression in ChG/AG is routinely assessed using the OLGA and OLGIM histological classifications [84,85]. However, molecular factors associated with GC progression in patients with IM still need to be characterized. According to Huang [65], there is a positive association between high levels of DNA methylation and IM progression. The presence of sCNAs and shortened telomeres are other molecular features associated with IM progression [65].

\subsection{Spasmolytic Polypeptide-Expressing Metaplasia}

Also known as pseudo-pyloric metaplasia, SPEM is a metaplastic process occurring in the gastric corpus and fundus characterized by morphologic and phenotypic features of antral glands without the G-cell component [86]. Strong expression of trefoil factor 2 (TFF2) and MUC6 are typically seen in SPEM [59]. Many studies have associated SPEM with GC, and it has been speculated that SPEM may play a role in GC carcinogenesis [87-89]. However, SPEM is not a defined step in Correa's cascade, and there is no agreement in considering SPEM a defined precursor lesion of IGAC and not a mere associated phenomenon $[86,90]$. Of note, results from studies on mouse models and human metaplastic tissues indicated that M2 macrophages may act as promoters of the advancement of SPEM in the presence of inflammation [91].

\subsection{Dysplasia}

Formerly known as intraepithelial neoplasia (IEN) or non-invasive neoplasia (NiN), gastric dysplasia is currently defined as unequivocal neoplastic changes of gastric epithelium without evidence of stromal invasion [14]. Low-grade dysplasia (LGD) presents minimal architectural disarray with mild to moderate cytologic atypia and mitotic activity. High-grade dysplasia (HGD) is characterized by cuboidal/columnar cells with marked cytologic atypia, brisk mitotic activity, high nucleus/cytoplasm ratio and prominent nucleoli together with a complex glandular architecture [14]. Risk of GC progression substantially increases from LGD (4-18\%) to HGD (up to 69\%) [92]. Moreover, within a year from initial diagnosis, patients with LGD and HGD have a risk of GC development, respectively, of $2.1 \%$ and $24.9 \%$ [93].

Analysis of low- and high-grade gastric dysplastic lesions displays a mean number of genetic regions with high-level sCNAs of 0.2 [94]. The frequency of sCNAs is higher in HGD than in LGD [95]. In the series of Uchida and colleagues [94], the most frequent sCNAs in gastric dysplasia were gains at 7q21.3-q22.1 (55\%), 8q (40\%) and 7pq (35\%), and loss at $5 \mathrm{q}(30 \%)$. In particular, gains at $7 \mathrm{pq}$ and $8 \mathrm{q}$ have been, respectively, reported in $54 \%$ and $62 \%$ of high-grade dysplasia but not in low-grade dysplasia. On the other hand, low-grade cases had more gains at 1q, 17q, 21q and 22q than high-grade dysplasia, while gains in 7q21.3-q22-1 and loss of $5 q$ presented similar frequencies in the two groups.

A median mutation density of 11.3 mutations/ $\mathrm{Mb}$ has been reported in gastric dysplasia, with $\mathrm{C}>\mathrm{T}$ transition being the most common mutation type, followed by $\mathrm{C}>\mathrm{A}$ and 
T > A [82]. Rokutan and colleagues [92] reported APC as the most frequently mutated gene in gastric dysplasia ( $76 \%$ of cases). According to their results, all LGDs and about a half of HGDs harbored APC mutations, and the co-occurrence of APC and ARID2 mutations was a common event. Despite the different mutational rate, APC mutations present identical hotspots in both LGD and HGD. This observation could support the hypothesis that APCmutated LGD and HGD are biologically related, with the latter being a progression of the former [92]. APC or TP53 mutations have been reported in about $88 \%$ of gastric dysplasia, with TP53 mutated exclusively in HGD. Interestingly, the risk of cancer progression seems to be higher in TP53-mutated gastric dysplasia than in APC-mutated ones $[92,96]$. This hypothesis is supported by the well-documented role of TP53 in GC progression [67,97]. Finally, mutations in ARID2, MUC6, TP53, KRAS, BRAF, PIK3CA and FBXW7 have also been described in both LGD and HGD [92,95].

TP53 is the most frequently mutated gene in HGD [67]. Other HGD-related mutations are described in APC, ATM, STK11, PIK3CA, RB1, CDKN2A, FGFR3, IDH2, MET, RNF43, RET and G0S2 $[14,67,93]$. Since most of these mutations have also been reported in invasive GC, they probably play an early role in gastric carcinogenesis [67]. In comparison to normal gastric mucosa, both LGD and HGD also present downregulation of BCL2L11, RET and $A L B$ and overexpression of $A E G-1$, GRIN2D and BRCA1 [98,99].

The expression of druggable molecules has also been reported in gastric dysplasia. HER2 overexpression and HER 2 amplification have been described in both LGD and HGD, being more frequent in the latter [100]. According to these results, HER2 dysregulation seems to be an early event in gastric carcinogenesis.

PD-L1 expression has also been documented in gastric dysplastic lesions, and it has been related to mismatch repair deficiency (MMRd) [101].

In comparison to normal mucosa, gastric dysplastic lesions and early gastric cancer (EGC) present downregulation of miRNA-26a, -375, -574-3p, -145 and -15b together with upregulation of miRNA-601, -107, 18a, -370, -300 and -96 [102]. Zhu and colleagues [103] report a gradual increase in miRNA-106a expression from LGD to HGD and EGC. Finally, dysregulation of miR-125a-5p/125b is an early event in gastric intestinal-type carcinogenesis. Interestingly, miR-125 expression has been inversely related to Her2 status, representing a possible therapeutic target in Her2-positive GC [104].

As regards epigenetic changes, $\mathrm{Hp}$ has been found to enhance histone $\mathrm{H} 3$ serine 10 phosphorylation within the progression from ChG to IM and finally to dysplasia. On the contrary, $\mathrm{Hp}$ is responsible for promoting gastric carcinogenesis via downregulation of the activity of many histone deacetylases (HDACs) (i.e., HDAC6, SIRT1) [105-107].

Understanding the molecular biology of gastric dysplastic lesions is a fascinating field and, as shown above, different studies have provided great knowledge on this matter. Despite having discovered many molecular alterations with a crucial role in gastric dysplasia development, a lack of comprehension concerning the biology of gastric dysplasia still remains. In particular, it is not clear whether LGD and HGD are strictly related, in a biological and molecular fashion. According to gene expression analysis of $\mathrm{Xu}$ and colleagues [93], there is a clear biological distinction between LGD and HGD. This hypothesis is also supported by other studies [64,92]. Fassan and colleagues [67] suggest that HGD is molecularly similar to EGC. Moreover, Hwang and colleagues [102] outline that gastric dysplastic lesions and EGC have different profiles of miRNA expression. In contrast, a recent study by Zhang and colleagues [98] reports that the gene expression profiles of LGD and HGD are more similar to each other than to that of EGC.

Another important factor significantly affecting a rapid comprehensive evaluation of the molecular background sustaining gastric dysplasia is the heterogeneous phenotypical landscape of gastric dysplasia itself. In fact, two main subtypes of gastric dysplasia have been described according to histological features and immunophenotyping: the intestinal and the gastric type. The gastric type can be further divided into the foveolar and pyloric types [4]. These lesions may occur de novo from the native gastric mucosa, outside the multistep GC carcinogenetic model, show features of biological aggressiveness and 
may represent the putative precursor lesion of gastric-type adenocarcinoma [108]. Mixed phenotypes are frequently observed in the clinical practice, and thus, most of the published molecular studies did not distinguish among the two major entities. Furthermore, most of the available data relate to intestinal-type dysplastic lesions. In a recent paper, Sugai and colleagues [109] investigated a relatively large series of intestinal-type and foveolar-type low-grade dysplastic lesions and found that foveolar-type dysplasia is characterized by a higher prevalence of allelic imbalance and a low methylation epigenotype.

\subsection{Special Type of Gastric Adenomas}

Besides the Correa's multistep GC carcinogenetic cascade, four distinct special-type gastric adenomas are described in the 2019 WHO classification [14]: the intestinal-type adenoma, the foveolar-type adenoma, the gastric pyloric gland adenoma and oxyntic gland adenoma.

Intestinal-type gastric adenoma differs from gastric dysplasia because of its polypoid nature. It may develop in the context of diffuse atrophic gastritis; therefore, its genetic landscape is similar to what has been described for the multistep carcinogenetic process and somewhat analogous to what has been observed in colorectal adenomas. In particular, these lesions are characterized by mutations in the APC, KRAS, ERBB2 and ARID2 genes but not alterations in CTNNB1 [110,111]. Some cases show a microsatellite instability phenotype. Syndromic cases typically occur as part of familial adenomatous polyposis.

Foveolar-type adenoma consists of a polypoid lesion covered by neoplastic foveolar epithelium that mostly occurs in an otherwise healthy oxyntic gastric compartment. Sporadic cases are rare, whereas most of the lesions are detected in the context of familial adenomatous polyposis and GAPPS [14]. Sporadic cases infrequently present mutations in the APC and KRAS genes [110].

Gastric pyloric gland adenomas are epithelial polyps consisting of neoplastic pylorictype glands. They are usually associated with atrophic changes of the oxyntic mucosa, e.g., those due to autoimmune and/or Hp-related gastritis [112], but they may also be associated with FAP. Most gastric pyloric gland adenomas feature activating mutations in GNAS and KRAS and inactivating APC mutations [113,114].

Oxyntic gland adenomas are benign neoplasms of the upper third of the stomach composed of columnar cells with differentiation to chief cells, parietal cells or both, mostly occurring in a non-atrophic oxyntic mucosa background [14]. This adenoma subtype is characterized by a high rate of progression to GC of fundic gland type. A third of the cases show missense or non-sense mutations in the WNT/ $\beta$-catenin pathway, except for CTNNB1 [115].

\section{Precursors of Diffuse Gastric Cancer}

Diffuse gastric cancer (DGC) accounts for nearly 30\% of GCs [15]. DGC is macroscopically characterized by a diffuse thickening of the gastric wall (i.e., linitis plastica) and usually presents a poorly cohesive histological phenotype. Loss of E-cadherin expression is the principal molecular feature of DGC [16]. DGC is usually sporadic, but familial clustering is reported in $10 \%$ of cases, and $1 \%$ to $3 \%$ arise in the context of a hereditary syndrome [116].

\subsection{Hereditary Diffuse Gastric Cancer}

HDGC accounts for 1-3\% of gastric cancers and usually presents at a young age [116].

The cumulative incidence of invasive GC by the age of 80 years is $70 \%$ in men and $56 \%$ in women. Individuals with HDGC also bear an increased risk of lobular breast carcinoma and possibly of colorectal carcinoma [117].

Germline mutations of CDH1 are the genetic basis of HDGC in up to $40 \%$ of cases [118]. To date, at least 100 pathological CDH1 germline mutations have been reported [119]. Small insertions and deletions represent the most common mutations (35\% of cases), followed by large exon deletions and missense mutations (28\%), non-sense mutations (16\%) and splice site mutations (16\%) [120]. 
Mutations of CTNNA1, PALB2, MYD88 and PIK3CA have also been related to HDGC [121]. Interestingly, HDGC patients with germline CDH1 mutations have lower survival rates than those with non-CDH1 germline mutations [122].

Based on the analysis of prophylactic gastrectomy of HDGC patients with CDH1 germline mutation, the Carneiro model proposes a carcinogenetic pathway to DGC [123]. According to this paradigm, the pivotal (but not obligatory [124]) precursor lesion is represented by signet ring cell carcinoma (SRCC) in situ. Histologically, in situ SRCCs are composed by signet ring cells with eccentric hyperchromatic nuclei and mucinous vacuoles confined in glands with an intact basement membrane [123]. A pagetoid spread of signet ring cells below normal foveolar epithelium is frequently recognized. Loss of E-cadherin expression is an early event, as it is already documented at the stage of in situ SRCC and subtending the phenotypic transition from normal gastric mucosa to preinvasive lesion [123]. E-cadherin loss is induced by an alteration of the second CDH1 allele [125]. About $50 \%$ of those second-hit inactivations is represented by $C D H 1$ promoter hypermethylation [126]. Other less frequent mechanisms are CDH1 mutations or loss of heterozygosity [127].

Complete loss of $\mathrm{CDH1}$ expression allows neoplastic cells to detach from the basement membrane, but other gene alterations are needed for the progression to invasive carcinoma [117]. For example, a strong expression of C-Src kinase (involved in epithelialmesenchymal transition) has been documented in neoplastic cells invading the muscularis mucosae but not in intramucosal signet ring cells [128]. Further studies are required to better comprehend the molecular biology of HDGC and to understand genetic and epigenetic alterations involved in DGC oncogenesis.

\subsection{Sporadic Diffuse Gastric Cancer}

Up to $70 \%$ of sporadic diffuse gastric cancers (SDGCs) harbor somatic mutations in CDH1 [59]. Moreover, somatic mutations of TTN have been reported in $40 \%$ of cases [129]. In contrast to HDGC, SDGC is strongly related to Hp infection $[130,131]$. Chan and colleagues [132] suggest that Hp may induce $C D H 1$ promoter methylation in non-neoplastic gastric mucosa and in gastric cancer. Hp eradication may lead to the reversion of methylation in non-neoplastic gastric mucosa [133].

A further clue that HDGC and SDGC may have different pathogenesis is provided by Lee and colleagues [134]. According to their results, HDGC cases are negative for CDX2, while SDGCs present CDX2 positivity. Moreover, a significant association between IM and SDGC development has been described [135], and OLGA/OLGIM stages III/IV have been associated not only with IGAC but also with DGC [136]. All together, these data suggest that SDGCs may develop from an "alternative" carcinogenetic pathway in the context of atrophic/metaplastic gastritis in which CDH1 mutations play a pivotal role.

\section{Conclusions}

GC still represents an aggressive and often deadly neoplasm. Despite great efforts to develop effective treatments, GC overall survival is unacceptably poor. Looking back on the recent past, two great successes in the fight against GC have been achieved thanks to a better comprehension of GC pathogenesis. The discovery of the role of Hp in GC has allowed the medical community to understand the importance of Hp eradication, with great benefits in terms of GC incidence and mortality reduction. Moreover, Correa's cascade has highlighted the multiphasic nature of intestinal-type gastric adenocarcinoma, permitting the development of effective programs of primary and secondary prevention. It is tempting to say that understanding the molecular landscape of pre-invasive gastric lesions could lead to the next milestone discovery in GC prevention. The rapidly accumulating data about the molecular alterations in GC carcinogenesis partially support this hope. The importance of methylation patterns and chromosome 8 status in IM evolution or TP53 mutational status in gastric dysplasia progression is not negligible: these data could be useful in improving the risk-assessment algorithms. Our ability to diagnose GC and/or 
gastric pre-invasive lesions could be improved by the use of molecular biomarkers, such as miRNAs. Moreover, the expression of druggable molecules such as Her2 and PD-L1 in gastric dysplasia should be taken into consideration in selecting patients for targeted therapeutic strategies. However, further efforts should be made to shed light on some obscure points. For example, the "point of no return" in gastric carcinogenesis remains elusive. Moreover, comprehensive knowledge about the biology of LGD and HGD and their relationship is still lacking. What is clear is that, in the era of precision oncology, a detailed molecular characterization of GC carcinogenesis represents a formidable tool to optimize the diagnostic and therapeutic decision-making process.

Author Contributions: Conceptualization, G.B., V.A., F.F., L.M., L.S. and M.F.; methodology, G.B., V.A., P.P., S.R. and E.S.; data curation, G.B., V.A., F.G. (Federica Grillo), A.V., F.G. (Francesca Galuppini), S.P. and G.P.; writing—original draft preparation, G.B., V.A., P.P., L.M., L.S. and M.F.; writingreview and editing, all the authors; supervision, F.F., L.M., L.S. and M.F.; funding acquisition, M.F. All authors have read and agreed to the published version of the manuscript.

Funding: This work was partially supported by a grant from the Italian Health Ministry and Veneto Region (NET-2016-02363853). The funding agency had no role in the design and performance of the study.

Institutional Review Board Statement: Not applicable.

Informed Consent Statement: Not applicable.

Data Availability Statement: Data available upon request.

Conflicts of Interest: The authors declare no conflict of interest regarding the present work.

\section{References}

1. Bray, F.; Ferlay, J.; Soerjomataram, I.; Siegel, R.L.; Torre, L.A.; Jemal, A. Global cancer statistics 2018: GLOBOCAN estimates of incidence and mortality worldwide for 36 cancers in 185 countries. CA Cancer J. Clin. 2018, 68, 394-424. [CrossRef]

2. Anderson, W.F.; Camargo, M.C.; Fraumeni, J.F.; Correa, P.; Rosenberg, P.S.; Rabkin, C.S. Age-specific trends in incidence of noncardia gastric cancer in US adults. JAMA 2010, 303, 1723-1728. [CrossRef]

3. Rubenstein, J.H.; Taylor, J.B. Meta-analysis: The association of oesophageal adenocarcinoma with symptoms of gastro-oesophageal reflux. Aliment. Pharmacol. Ther. 2010, 32, 1222-1227. [CrossRef]

4. Gullo, I.; Grillo, F.; Mastracci, L.; Vanoli, A.; Carneiro, F.; Saragoni, L.; Limarzi, F.; Ferro, J.; Parente, P.; Fassan, M. Precancerous lesions of the stomach, gastric cancer and hereditary gastric cancer syndromes. Pathologica 2020, 112, 166-185. [CrossRef]

5. Choi, Y.J.; Kim, N. Gastric cancer and family history. Korean J. Intern. Med. 2016, 31, 1042-1053. [CrossRef] [PubMed]

6. Stolte, M.; Bayerdörffer, E.; Morgner, A.; Alpen, B.; Wündisch, T.; Thiede, C.; Neubauer, A. Helicobacter and gastric MALT lymphoma. Gut 2002, 50 (Suppl. S3), III19-III24. [CrossRef] [PubMed]

7. Toh, J.W.T.; Wilson, R.B. Pathways of gastric carcinogenesis, Helicobacter pylori virulence and interactions with antioxidant systems, vitamin C and phytochemicals. Int. J. Mol. Sci. 2020, 21, 6451. [CrossRef]

8. Rugge, M.; Genta, R.M.; Di Mario, F.; El-Omar, E.M.; El-Serag, H.B.; Fassan, M.; Hunt, R.H.; Kuipers, E.J.; Malfertheiner, P.; Sugano, K.; et al. Gastric cancer as preventable disease. Clin. Gastroenterol. Hepatol. 2017, 15, 1833-1843. [CrossRef] [PubMed]

9. Carvalho, J.; Oliveira, P.; Senz, J.; São José, C.; Hansford, S.; Teles, S.P.; Ferreira, M.; Corso, G.; Pinheiro, H.; Lemos, D.; et al. Redefinition of familial intestinal gastric cancer: Clinical and genetic perspectives. J. Med. Genet. 2021, 58, 1-11. [CrossRef]

10. Spoto, C.P.E.; Gullo, I.; Carneiro, F.; Montgomery, E.A.; Brosens, L.A.A. Hereditary gastrointestinal carcinomas and their precursors: An algorithm for genetic testing. Semin. Diagn. Pathol. 2018, 35, 170-183. [CrossRef]

11. Van der Post, R.S.; Carneiro, F. Emerging concepts in gastric neoplasia: Heritable gastric cancers and polyposis disorders. Surg. Pathol. Clin. 2017, 10, 931-945. [CrossRef]

12. Sandoval-Bórquez, A.; Saavedra, K.; Carrasco-Avino, G.; Garcia-Bloj, B.; Fry, J.; Wichmann, I.; Corvalán, A.H. Noncoding genomics in gastric cancer and the gastric precancerous cascade: Pathogenesis and biomarkers. Dis. Markers 2015, $2015,503762$. [CrossRef]

13. Businello, G.; Galuppini, F.; Fassan, M. The impact of recent next generation sequencing and the need for a new classification in gastric cancer. Best Pract. Res. Clin. Gastroenterol. 2021, 50-51, 101730. [CrossRef] [PubMed]

14. WHO. Classification of Tumours Editorial Board. Digestive System Tumours; International Agency for Research on Cancer: Lyon, France, 2019.

15. Lauren, P. The two histological main types of gastric carcinoma: Diffuse and so-called intestinal-type carcinoma. An attempt at a histo-clinical classification. Acta Pathol. Microbiol. Scand. 1965, 64, 31-49. [CrossRef]

16. Graziano, F.; Humar, B.; Guilford, P. The role of the E-cadherin gene (CDH1) in diffuse gastric cancer susceptibility: From the laboratory to clinical practice. Ann. Oncol. 2003, 14, 1705-1713. [CrossRef] 
17. Network CGAR. Comprehensive molecular characterization of gastric adenocarcinoma. Nature 2014, 513, 202-209. [CrossRef] [PubMed]

18. Cristescu, R.; Lee, J.; Nebozhyn, M.; Kim, K.M.; Ting, J.C.; Wong, S.S.; Liu, J.; Yue, Y.G.; Wang, J.; Yu, K.; et al. Molecular analysis of gastric cancer identifies subtypes associated with distinct clinical outcomes. Nat. Med. 2015, 21, 449-456. [CrossRef] [PubMed]

19. Nakamura, Y.; Kawazoe, A.; Lordick, F.; Janjigian, Y.Y.; Shitara, K. Biomarker-targeted therapies for advanced-stage gastric and gastro-oesophageal junction cancers: An emerging paradigm. Nat. Rev. Clin. Oncol. 2021, 18, 473-487. [CrossRef] [PubMed]

20. Bang, Y.J.; Van Cutsem, E.; Feyereislova, A.; Chung, H.C.; Shen, L.; Sawaki, A.; Lordick, F.; Ohtsu, A.; Omuro, Y.; Satoh, T.; et al. ToGA Trial Investigators. Trastuzumab in combination with chemotherapy versus chemotherapy alone for treatment of HER2-positive advanced gastric or gastro-oesophageal junction cancer (ToGA): A phase 3, open-label, randomised controlled trial. Lancet 2010, 28, 687-697. [CrossRef]

21. Shitara, K.; Bang, Y.J.; Iwasa, S.; Sugimoto, N.; Ryu, M.H.; Sakai, D.; Chung, H.C.; Kawakami, H.; Yabusaki, H.; Lee, J.; et al. DESTINY-Gastric01 investigators. Trastuzumab deruxtecan in previously treated HER2-positive gastric cancer. N. Engl. J. Med. 2020, 18, 2419-2430. [CrossRef]

22. Wainberg, Z.A.; Enzinger, P.C.; Kang, Y.K.; Yamaguchi, K.; Qin, S.; Lee, K.W.; Oh, S.C.; Li, J.; Turk, H.M.; Teixeira, A.C.; et al. Randomized double-blind placebo-controlled phase 2 study of bemarituzumab combined with modified FOLFOX6 (mFOLFOX6) in first-line (1L) treatment of advanced gastric/gastroesophageal junction adenocarcinoma (FIGHT). J. Clin. Oncol. 2021, 39 (Suppl. S3), 160. [CrossRef]

23. Catenacci, D.V.; Tesfaye, A.; Tejani, M.; Cheung, E.; Eisenberg, P.; Scott, A.J.; Eng, C.; Hnatyszyn, J.; Marina, N.; Powers, J.; et al. Bemarituzumab with modified FOLFOX6 for advanced FGFR2-positive gastroesophageal cancer: FIGHT Phase III study design. Future Oncol. 2019, 15, 2073-2082. [CrossRef]

24. Shah, M.A.; Bang, Y.J.; Lordick, F.; Alsina, M.; Chen, M.; Hack, S.P.; Bruey, J.M.; Smith, D.; McCaffery, I.; Shames, D.S.; et al. Effect of fluorouracil, leucovorin, and oxaliplatin with or without onartuzumab in HER2-Negative, MET-positive gastroesophageal adenocarcinoma: The METGastric randomized clinical trial. JAMA Oncol. 2017, 3, 620-627. [CrossRef]

25. Lee, J.; Kim, S.T.; Kim, K.; Lee, H.; Kozarewa, I.; Mortimer, P.G.S.; Odegaard, J.I.; Harrington, E.A.; Lee, J.; Lee, T.; et al. Tumor genomic profiling guides patients with metastatic gastric cancer to targeted treatment: The VIKTORY umbrella trial. Cancer Discov. 2019, 9, 1388-1405. [CrossRef]

26. Fuchs, C.S.; Tomasek, J.; Yong, C.J.; Dumitru, F.; Passalacqua, R.; Goswami, C.; Safran, H.; Dos Santos, L.V.; Aprile, G.; Ferry, D.R.; et al. REGARD Trial Investigators. Ramucirumab monotherapy for previously treated advanced gastric or gastro-oesophageal junction adenocarcinoma (REGARD): An international, randomised, multicentre, placebo-controlled, phase 3 trial. Lancet 2014, 383, 31-39. [CrossRef]

27. Wilke, H.; Muro, K.; Van Cutsem, E.; Oh, S.C.; Bodoky, G.; Shimada, Y.; Hironaka, S.; Sugimoto, N.; Lipatov, O.; Kim, T.Y.; et al. Ramucirumab plus paclitaxel versus placebo plus paclitaxel in patients with previously treated advanced gastric or gastro-oesophageal junction adenocarcinoma (RAINBOW): A double-blind, randomised phase 3 trial. Lancet Oncol. 2014, 15, 1224-1235. [CrossRef]

28. Sahin, U.; Türeci, Ö.; Manikhas, G.; Lordick, F.; Rusyn, A.; Vynnychenko, I.; Dudov, A.; Bazin, I.; Bondarenko, I.; Melichar, B.; et al. FAST: A randomised phase II study of zolbetuximab (IMAB362) plus EOX versus EOX alone for first-line treatment of advanced CLDN18.2-positive gastric and gastro-oesophageal adenocarcinoma. Ann. Oncol. 2021, 32, 609-619. [CrossRef]

29. Moehler, M.; Shitara, K.; Garrido, M.; Salman, P.; Shen, L.; Wyrwicz, L.; Yamaguchi, K.; Skoczylas, T.; Campos Bragagnoli, A.; Liu, T.; et al. Nivolumab (nivo) plus chemotherapy (chemo) versus chemo as first-line (1L) treatment for advanced gastric cancer/gastroesophageal junction cancer (GC/GEJC)/esophageal adenocarcinoma (EAC): First results of the CheckMate 649 study. Ann. Oncol. 2020, 31 (Suppl. S4), S1142-S1215. [CrossRef]

30. Boku, N.; Ryu, M.H.; Oh, D.; Oh, S.C.; Chung, H.C.; Lee, K.; Omori, T.; Shitara, K.; Sakuramoto, S.; Chung, I.J.; et al. Nivolumab plus chemotherapy versus chemotherapy alone in patients with previously untreated advanced or recurrent gastric/gastroesophageal junction (G/GEJ) cancer: ATTRACTION-4 (ONO-4538-37) study. Ann. Oncol. 2020, 31 (Suppl. S4), S1142-S1215. [CrossRef]

31. Kang, Y.K.; Boku, N.; Satoh, T.; Ryu, M.H.; Chao, Y.; Kato, K.; Chung, H.C.; Chen, J.S.; Muro, K.; Kang, W.K.; et al. Nivolumab in patients with advanced gastric or gastro-oesophageal junction cancer refractory to, or intolerant of, at least two previous chemotherapy regimens (ONO-4538-12, ATTRACTION-2): A randomised, double-blind, placebo-controlled, phase 3 trial. Lancet 2017, 390, 2461-2471. [CrossRef]

32. Correa, P.; Haenszel, W.; Cuello, C.; Tannenbaum, S.; Archer, M. A model for gastric cancer epidemiology. Lancet 1975, 2, 58-60. [CrossRef]

33. Rugge, M.; Meggio, A.; Pennelli, G.; Piscioli, F.; Giacomelli, L.; De Pretis, G.; Graham, D.Y. Gastritis staging in clinical practice: The OLGA staging system. Gut 2007, 56, 631-636. [CrossRef] [PubMed]

34. Correa, P.; Piazuelo, M.B. The gastric precancerous cascade. J. Dig. Dis. 2012, 13, 2-9. [CrossRef]

35. Kawanishi, S.; Hiraku, Y.; Oikawa, S. Mechanism of guanine-specific DNA damage by oxidative stress and its role in carcinogenesis and aging. Mutat. Res. 2001, 488, 65-76. [CrossRef]

36. Hussain, S.P.; Harris, C.C. Inflammation and cancer: An ancient link with novel potentials. Int. J. Cancer 2007, 121, 2373-2380. [CrossRef] 
37. Hatakeyama, M. Structure and function of Helicobacter pylori CagA, the first-identified bacterial protein involved in human cancer. Proc. Jpn. Acad. Ser. B Phys. Biol. Sci. 2017, 93, 196-219. [CrossRef] [PubMed]

38. Shimizu, T.; Marusawa, H.; Matsumoto, Y.; Inuzuka, T.; Ikeda, A.; Fujii, Y.; Minamiguchi, S.; Miyamoto, S.; Kou, T.; Sakai, Y.; et al. Accumulation of somatic mutations in TP53 in gastric epithelium with Helicobacter pylori infection. Gastroenterology 2014, 147, 407-417.e3. [CrossRef]

39. Matsumoto, T.; Shimizu, T.; Takai, A.; Marusawa, H. Exploring the mechanisms of gastrointestinal cancer development using deep sequencing analysis. Cancers 2015, 7, 1037-1051. [CrossRef] [PubMed]

40. Zhu, Y.; Jiang, Q.; Lou, X.; Ji, X.; Wen, Z.; Wu, J.; Tao, H.; Jiang, T.; He, W.; Wang, C.; et al. MicroRNAs up-regulated by CagA of Helicobacter pylori induce intestinal metaplasia of gastric epithelial cells. PLoS ONE 2012, 7, e35147. [CrossRef]

41. Liu, S.; Yin, H.; Zheng, S.; Chu, A.; Li, Y.; Xing, C.; Yuan, Y.; Gong, Y. Differentially expressed mRNAs and their long noncoding RNA regulatory network with Helicobacter pylori-associated diseases including atrophic gastritis and gastric cancer. Biomed. Res. Int. 2020, 2020, 3012193. [CrossRef]

42. Petkevicius, V.; Streleckiene, G.; Balciute, K.; Link, A.; Leja, M.; Malfertheiner, P.; Skieceviciene, J.; Kupcinskas, J. Association of long non-coding RNA polymorphisms with gastric cancer and atrophic gastritis. Genes 2020, 11, 1505. [CrossRef]

43. Mao, Y.; Liu, R.; Zhou, H.; Yin, S.; Zhao, Q.; Ding, X.; Wang, H. Transcriptome analysis of miRNA-lncRNA-mRNA interactions in the malignant transformation process of gastric cancer initiation. Cancer Gene Ther. 2017, 24, 267-275. [CrossRef]

44. Zhou, X.; Chen, H.; Zhu, L.; Hao, B.; Zhang, W.; Hua, J.; Gu, H.; Jin, W.; Zhang, G. Helicobacter pylori infection related long noncoding RNA (lncRNA) AF147447 inhibits gastric cancer proliferation and invasion by targeting MUC2 and up-regulating miR-34c. Oncotarget 2016, 7, 82770-82782. [CrossRef] [PubMed]

45. Coker, O.O.; Dai, Z.; Nie, Y.; Zhao, G.; Cao, L.; Nakatsu, G.; Wu, W.K.; Wong, S.H.; Chen, Z.; Sung, J.J.Y.; et al. Mucosal microbiome dysbiosis in gastric carcinogenesis. Gut 2018, 67, 1024-1032. [CrossRef] [PubMed]

46. Wang, Z.; Gao, X.; Zeng, R.; Wu, Q.; Sun, H.; Wu, W.; Zhang, X.; Sun, G.; Yan, B.; Wu, L.; et al. Changes of the Gastric Mucosal Microbiome associated with histological stages of gastric carcinogenesis. Front. Microbiol. 2020, 11, 997. [CrossRef]

47. Sung, J.J.Y.; Coker, O.O.; Chu, E.; Szeto, C.H.; Luk, S.T.Y.; Lau, H.C.H.; Yu, J. Gastric microbes associated with gastric inflammation, atrophy and intestinal metaplasia 1 year after Helicobacter pylori eradication. Gut 2020, 69, 1572-1580. [CrossRef] [PubMed]

48. Negovan, A.; Iancu, M.; Fülöp, E.; Bănescu, C. Helicobacter pylori and cytokine gene variants as predictors of premalignant gastric lesions. World J. Gastroenterol. 2019, 25, 4105-4124. [CrossRef]

49. Fu, H.; Ma, Y.; Yang, M.; Zhang, C.; Huang, H.; Xia, Y.; Lu, L.; Jin, W.; Cui, D. Persisting and increasing neutrophil infiltration associates with gastric carcinogenesis and E-cadherin downregulation. Sci. Rep. 2016, 6, 29762. [CrossRef]

50. Coati, I.; Fassan, M.; Farinati, F.; Graham, D.Y.; Genta, R.M.; Rugge, M. Autoimmune gastritis: Pathologist's viewpoint. World J. Gastroenterol. 2015, 21, 12179-12189. [CrossRef]

51. Vannella, L.; Lahner, E.; Osborn, J.; Annibale, B. Systematic review: Gastric cancer incidence in pernicious anaemia. Aliment. Pharmacol. Ther. 2013, 37, 375-382. [CrossRef]

52. Elsborg, L.; Mosbech, J. Pernicious anaemia as a risk factor in gastric cancer. Acta Med. Scand. 1979, 206, 315-318. [CrossRef]

53. Rugge, M.; Fassan, M.; Pizzi, M.; Zorzetto, V.; Maddalo, G.; Realdon, S.; De Bernard, M.; Betterle, C.; Cappellesso, R.; Pennelli, G.; et al. Autoimmune gastritis: Histology phenotype and OLGA staging. Aliment. Pharmacol. Ther. 2012, 35, 1460-1466. [CrossRef] [PubMed]

54. Bizzaro, N.; Antico, A.; Villalta, D. Autoimmunity and gastric cancer. Int. J. Mol. Sci. 2018, 19, 377. [CrossRef]

55. Huang, F.Y.; Chan, A.O.; Rashid, A.; Wong, D.K.; Seto, W.K.; Cho, C.H.; Lai, C.L.; Yuen, M.F. Interleukin-1 $\beta$ increases the risk of gastric cancer through induction of aberrant DNA methylation in a mouse model. Oncol. Lett. 2016, 11, 2919-2924. [CrossRef]

56. De Vries, A.C.; van Grieken, N.C.; Looman, C.W.; Casparie, M.K.; de Vries, E.; Meijer, G.A.; Kuipers, E.J. Gastric cancer risk in patients with premalignant gastric lesions: A nationwide cohort study in the Netherlands. Gastroenterology 2008, 134, 945-952. [CrossRef]

57. Li, D.; Bautista, M.C.; Jiang, S.F.; Daryani, P.; Brackett, M.; Armstrong, M.A.; Hung, Y.Y.; Postlethwaite, D.; Ladabaum, U. Risks and predictors of gastric adenocarcinoma in patients with gastric intestinal metaplasia and dysplasia: A Population-based study. Am. J. Gastroenterol. 2016, 111, 1104-1113. [CrossRef]

58. Filipe, M.I.; Potet, F.; Bogomoletz, W.V.; Dawson, P.A.; Fabiani, B.; Chauveinc, P.; Fenzy, A.; Gazzard, B.; Goldfain, D.; Zeegen, R. Incomplete sulphomucin-secreting intestinal metaplasia for gastric cancer. Preliminary data from a prospective study from three centres. Gut 1985, 26, 1319-1326. [CrossRef]

59. Yakirevich, E.; Resnick, M.B. Pathology of gastric cancer and its precursor lesions. Gastroenterol. Clin. 2013, 42, 261-284. [CrossRef] [PubMed]

60. Camilo, V.; Garrido, M.; Valente, P.; Ricardo, S.; Amaral, A.L.; Barros, R.; Chaves, P.; Carneiro, F.; David, L.; Almeida, R. Differentiation reprogramming in gastric intestinal metaplasia and dysplasia: Role of SOX2 and CDX2. Histopathology 2015, 66, 343-350. [CrossRef] [PubMed]

61. González, C.A.; Sanz-Anquela, J.M.; Gisbert, J.P.; Correa, P. Utility of subtyping intestinal metaplasia as marker of gastric cancer risk. A review of the evidence. Int. J. Cancer 2013, 133, 1023-1032. [CrossRef] [PubMed]

62. González, C.A.; Sanz-Anquela, J.M.; Companioni, O.; Bonet, C.; Berdasco, M.; López, C.; Mendoza, J.; Martín-Arranz, M.D.; Rey, E.; Poves, E.; et al. Incomplete type of intestinal metaplasia has the highest risk to progress to gastric cancer: Results of the Spanish follow-up multicenter study. J. Gastroenterol. Hepatol. 2016, 31, 953-958. [CrossRef] [PubMed] 
63. Pittayanon, R.; Rerknimitr, R.; Klaikaew, N.; Sanpavat, A.; Chaithongrat, S.; Mahachai, V.; Kullavanijaya, P.; Barkun, A. The risk of gastric cancer in patients with gastric intestinal metaplasia in 5-year follow-up. Aliment. Pharmacol. Ther. 2017, 46, 40-45. [CrossRef] [PubMed]

64. Koulis, A.; Buckle, A.; Boussioutas, A. Premalignant lesions and gastric cancer: Current understanding. World J. Gastrointest. Oncol. 2019, 11, 665-678. [CrossRef] [PubMed]

65. Huang, K.K.; Ramnarayanan, K.; Zhu, F.; Srivastava, S.; Xu, C.; Tan, A.L.K.; Lee, M.; Tay, S.; Das, K.; Xing, M.; et al. Genomic and epigenomic profiling of high-risk intestinal metaplasia reveals molecular determinants of progression to gastric cancer. Cancer Cell 2018, 33, 137-150.e5. [CrossRef]

66. Tahara, E. Genetic pathways of two types of gastric cancer. IARC Sci. Publ. 2004, 6, 327-349.

67. Fassan, M.; Simbolo, M.; Bria, E.; Mafficini, A.; Pilotto, S.; Capelli, P.; Bencivenga, M.; Pecori, S.; Luchini, C.; Neves, D.; et al. High-throughput mutation profiling identifies novel molecular dysregulation in high-grade intraepithelial neoplasia and early gastric cancers. Gastric Cancer 2014, 17, 442-449. [CrossRef]

68. Mu, Y.; Zhang, Q.; Mei, L.; Liu, X.; Yang, W.; Yu, J. Telomere shortening occurs early during gastrocarcinogenesis. Med. Oncol. 2012, 29, 893-898. [CrossRef]

69. Lin, R.; Li, C.; Liu, Z.; Wu, R.; Lu, J. Genome-wide DNA methylation profiling identifies epigenetic signatures of gastric cardiac intestinal metaplasia. J. Transl. Med. 2020, 18, 292. [CrossRef]

70. Hamamoto, T.; Yokozaki, H.; Semba, S.; Yasui, W.; Yunotani, S.; Miyazaki, K.; Tahara, E. Altered microsatellites in incomplete-type intestinal metaplasia adjacent to primary gastric cancers. J. Clin. Pathol. 1997, 50, 841-846. [CrossRef]

71. Cortés-Márquez, A.C.; Mendoza-Elizalde, S.; Arenas-Huertero, F.; Trillo-Tinoco, J.; Valencia-Mayoral, P.; Consuelo-Sánchez, A.; Zarate-Franco, J.; Dionicio-Avendaño, A.R.; Herrera-Esquivel, J.J.; Recinos-Carrera, E.G.; et al. Differential expression of miRNA-146a and miRNA-155 in gastritis induced by Helicobacter pylori infection in paediatric patients, adults, and an animal model. BMC Infect. Dis. 2018, 18, 463. [CrossRef]

72. Li, H.; Wu, Q.; Li, T.; Liu, C.; Xue, L.; Ding, J.; Shi, Y.; Fan, D. The miR-17-92 cluster as a potential biomarker for the early diagnosis of gastric cancer: Evidence and literature review. Oncotarget 2017, 8, 45060-45071. [CrossRef] [PubMed]

73. Qu, M.; Li, L.; Zheng, W.C. Reduced miR-490-3p expression is associated with poor prognosis of Helicobacter pylori induced gastric cancer. Eur. Rev. Med. Pharmacol. Sci. 2017, 21, 3384-3388.

74. Shen, J.; Xiao, Z.; Wu, W.K.; Wang, M.H.; To, K.F.; Chen, Y.; Yang, W.; Li, M.S.; Shin, V.Y.; Tong, J.H.; et al. Epigenetic silencing of miR-490-3p reactivates the chromatin remodeler SMARCD1 to promote Helicobacter pylori-induced gastric carcinogenesis. Cancer Res. 2015, 75, 754-765. [CrossRef]

75. Min, J.; Han, T.S.; Sohn, Y.; Shimizu, T.; Choi, B.; Bae, S.W.; Hur, K.; Kong, S.H.; Suh, Y.S.; Lee, H.J.; et al. microRNA-30a arbitrates intestinal-type early gastric carcinogenesis by directly targeting ITGA2. Gastric Cancer 2020, 23, 600-613. [CrossRef] [PubMed]

76. Wang, X.W.; Wu, Y.; Wang, D.; Qin, Z.F. MicroRNA network analysis identifies key microRNAs and genes associated with precancerous lesions of gastric cancer. Genet. Mol. Res. 2014, 13, 8695-8703. [CrossRef]

77. Rokkas, T.; Pistiolas, D.; Sechopoulos, P.; Robotis, I.; Margantinis, G. The long-term impact of Helicobacter pylori eradication on gastric histology: A systematic review and meta-analysis. Helicobacter 2007, 12 (Suppl. S2), 32-38. [CrossRef] [PubMed]

78. Wang, J.; Xu, L.; Shi, R.; Huang, X.; Li, S.W.; Huang, Z.; Zhang, G. Gastric atrophy and intestinal metaplasia before and after Helicobacter pylori eradication: A meta-analysis. Digestion 2011, 83, 253-260. [CrossRef] [PubMed]

79. Shin, C.M.; Kim, N.; Chang, H.; Kim, J.S.; Lee, D.H.; Jung, H.C. Follow-up study on CDX1 and CDX2 mRNA expression in noncancerous gastric mucosae after Helicobacter pylori eradication. Dig. Dis. Sci. 2016, 61, 1051-1059. [CrossRef] [PubMed]

80. Chen, H.N.; Wang, Z.; Li, X.; Zhou, Z.G. Helicobacter pylori eradication cannot reduce the risk of gastric cancer in patients with intestinal metaplasia and dysplasia: Evidence from a meta-analysis. Gastric Cancer 2016, 19, 166-175. [CrossRef] [PubMed]

81. Kang, J.M.; Kim, N.; Shin, C.M.; Lee, H.S.; Lee, D.H.; Jung, H.C.; Song, I.S. Predictive factors for improvement of atrophic gastritis and intestinal metaplasia after Helicobacter pylori eradication: A three-year follow-up study in Korea. Helicobacter 2012, 17, 86-95. [CrossRef]

82. Lee, Y.C.; Chen, T.H.; Chiu, H.M.; Shun, C.T.; Chiang, H.; Liu, T.Y.; Wu, M.S.; Lin, J.T. The benefit of mass eradication of Helicobacter pylori infection: A community-based study of gastric cancer prevention. Gut 2013, 62, 676-682. [CrossRef]

83. Den Hollander, W.J.; Holster, I.L.; den Hoed, C.M.; Capelle, L.G.; Tang, T.J.; Anten, M.P.; Prytz-Berset, I.; Witteman, E.M.; Ter Borg, F.; Hartog, G.D.; et al. Surveillance of premalignant gastric lesions: A multicentre prospective cohort study from low incidence regions. Gut 2019, 68, 585-593. [CrossRef]

84. Rugge, M.; de Boni, M.; Pennelli, G.; de Bona, M.; Giacomelli, L.; Fassan, M.; Basso, D.; Plebani, M.; Graham, D.Y. Gastritis OLGA-staging and gastric cancer risk: A twelve-year clinico-pathological follow-up study. Aliment. Pharmacol Ther. 2010, 31, 1104-1111. [CrossRef]

85. Rugge, M.; Fassan, M.; Pizzi, M.; Farinati, F.; Sturniolo, G.C.; Plebani, M.; Graham, D.Y. Operative link for gastritis assessment vs. operative link on intestinal metaplasia assessment. World J. Gastroenterol. 2011, 17, 4596-4601. [CrossRef] [PubMed]

86. Goldenring, J.R.; Nam, K.T.; Wang, T.C.; Mills, J.C.; Wright, N.A. Spasmolytic polypeptide-expressing metaplasia and intestinal metaplasia: Time for reevaluation of metaplasias and the origins of gastric cancer. Gastroenterology 2010, 138, 2207-2210. [CrossRef] [PubMed]

87. Schmidt, P.H.; Lee, J.R.; Joshi, V.; Playford, R.J.; Poulsom, R.; Wright, N.A.; Goldenring, J.R. Identification of a metaplastic cell lineage associated with human gastric adenocarcinoma. Lab. Investig. 1999, 79, 639-646. 
88. Halldórsdóttir, A.M.; Sigurdardóttrir, M.; Jónasson, J.G.; Oddsdóttir, M.; Magnússon, J.; Lee, J.R.; Goldenring, J.R. Spasmolytic polypeptide-expressing metaplasia (SPEM) associated with gastric cancer in Iceland. Dig. Dis. Sci. 2003, 48, 431-441. [CrossRef] [PubMed]

89. Yamaguchi, H.; Goldenring, J.R.; Kaminishi, M.; Lee, J.R. Identification of spasmolytic polypeptide expressing metaplasia (SPEM) in remnant gastric cancer and surveillance postgastrectomy biopsies. Dig. Dis. Sci. 2002, 47, 573-578. [CrossRef]

90. Goldenring, J.R.; Nam, K.T. Oxyntic atrophy, metaplasia, and gastric cancer. Prog. Mol. Biol. Transl. Sci. 2010, 96, 117-131.

91. Petersen, C.P.; Weis, V.G.; Nam, K.T.; Sousa, J.F.; Fingleton, B.; Goldenring, J.R. Macrophages promote progression of spasmolytic polypeptide-expressing metaplasia after acute loss of parietal cells. Gastroenterology 2014, 146, 1727-1738.e8. [CrossRef]

92. Rokutan, H.; Abe, H.; Nakamura, H.; Ushiku, T.; Arakawa, E.; Hosoda, F.; Yachida, S.; Tsuji, Y.; Fujishiro, M.; Koike, K.; et al. Initial and crucial genetic events in intestinal-type gastric intramucosal neoplasia. J. Pathol. 2019, 247, 494-504. [CrossRef] [PubMed]

93. Xu, X.; Feng, L.; Liu, Y.; Zhou, W.X.; Ma, Y.C.; Fei, G.J.; An, N.; Li, Y.; Wu, X.; Yao, F.; et al. Differential gene expression profiling of gastric intraepithelial neoplasia and early-stage adenocarcinoma. World J. Gastroenterol. 2014, 20, 17883-17893. [CrossRef] [PubMed]

94. Uchida, M.; Tsukamoto, Y.; Uchida, T.; Ishikawa, Y.; Nagai, T.; Hijiya, N.; Nguyen, L.T.; Nakada, C.; Kuroda, A.; Okimoto, T.; et al. Genomic profiling of gastric carcinoma in situ and adenomas by array-based comparative genomic hybridization. J. Pathol. 2010, 221, 96-105. [CrossRef]

95. Sugai, T.; Eizuka, M.; Arakawa, N.; Osakabe, M.; Habano, W.; Fujita, Y.; Yamamoto, E.; Yamano, H.; Endoh, M.; Matsumoto, T.; et al. Molecular profiling and comprehensive genome-wide analysis of somatic copy number alterations in gastric intramucosal neoplasias based on microsatellite status. Gastric Cancer 2018, 21, 765-775. [CrossRef]

96. Lee, J.H.; Abraham, S.C.; Kim, H.S.; Nam, J.H.; Choi, C.; Lee, M.C.; Park, C.S.; Juhng, S.W.; Rashid, A.; Hamilton, S.R.; et al. Inverse relationship between APC gene mutation in gastric adenomas and development of adenocarcinoma. Am. J. Pathol. 2002, 161, 611-618. [CrossRef]

97. Sakurai, S.; Sano, T.; Nakajima, T. Clinicopathological and molecular biological studies of gastric adenomas with special reference to p53 abnormality. Pathol. Int. 1995, 45, 51-57. [CrossRef]

98. Zhang, Y.; Wu, X.; Zhang, C.; Wang, J.; Fei, G.; Di, X.; Lu, X.; Feng, L.; Cheng, S.; Yang, A. Dissecting expression profiles of gastric precancerous lesions and early gastric cancer to explore crucial molecules in intestinal-type gastric cancer tumorigenesis. J. Pathol. 2020, 251, 135-146. [CrossRef] [PubMed]

99. Huang, W.; Yang, L.; Liang, S.; Liu, D.; Chen, X.; Ma, Z.; Zhai, S.; Li, P.; Wang, X. AEG-1 is a target of perifosine and is over-expressed in gastric dysplasia and cancers. Dig. Dis. Sci. 2013, 58, 2873-2880. [CrossRef]

100. Fassan, M.; Mastracci, L.; Grillo, F.; Zagonel, V.; Bruno, S.; Battaglia, G.; Pitto, F.; Nitti, D.; Celiento, T.; Zaninotto, G.; et al. Early HER2 dysregulation in gastric and oesophageal carcinogenesis. Histopathology 2012, 61, 769-776. [CrossRef]

101. Fassan, M.; Brignola, S.; Pennelli, G.; Alberti, G.; Angerilli, V.; Bressan, A.; Pellino, A.; Lanza, C.; Salmaso, R.; Lonardi, S.; et al PD-L1 expression in gastroesophageal dysplastic lesions. Virchows Arch. 2020, 477, 151-156. [CrossRef]

102. Hwang, J.; Min, B.H.; Jang, J.; Kang, S.Y.; Bae, H.; Jang, S.S.; Kim, J.I.; Kim, K.M. MicroRNA Expression profiles in gastric carcinogenesis. Sci. Rep. 2018, 8, 14393. [CrossRef]

103. Zhu, M.; Zhang, N.; He, S. Similarly up-regulated microRNA-106a in matched formalin-fixed paraffin-embedded and fresh frozen samples and the dynamic changes during gastric carcinogenesis and development. Pathol. Res. Pract. 2014, 210, 909-915. [CrossRef]

104. Fassan, M.; Pizzi, M.; Realdon, S.; Balistreri, M.; Guzzardo, V.; Zagonel, V.; Castoro, C.; Mastracci, L.; Farinati, F.; Nitti, D.; et al. The HER2-miR125a5p/miR125b loop in gastric and esophageal carcinogenesis. Hum. Pathol. 2013, 44, 1804-1810. [CrossRef] [PubMed]

105. Yang, Y.X.; Ding, S.Z. Helicobacter pylori infection-induced H3Ser10 phosphorylation in stepwise gastric carcinogenesis and its clinical implications. Helicobacter 2018, 23, e12486. [CrossRef] [PubMed]

106. He, Q.; Li, G.; Wang, X.; Wang, S.; Hu, J.; Yang, L.; He, Y.; Pan, Y.; Yu, D.; Wu, Y. A decrease of histone deacetylase 6 expression caused by Helicobacter pylori infection is associated with oncogenic transformation in gastric cancer. Cell Physiol. Biochem. 2017, 42, 1326-1335. [CrossRef]

107. Wang, X.; Wang, B.; Gao, W.; An, Y.; Dong, G.; Jia, J.; Yang, Q. Helicobacter pylori inhibits autophagic flux and promotes its intracellular survival and colonization by down-regulating SIRT1. J. Cell. Mol. Med. 2021, 25, 3348-3360. [CrossRef]

108. Valente, P.; Garrido, M.; Gullo, I.; Baldaia, H.; Marques, M.; Baldaque-Silva, F.; Lopes, J.; Carneiro, F. Epithelial dysplasia of the stomach with gastric immunophenotype shows features of biological aggressiveness. Gastric Cancer 2015, 18, 720-728. [CrossRef]

109. Sugai, T.; Uesugi, N.; Habano, W.; Sugimoto, R.; Eizuka, M.; Fujita, Y.; Osakabe, M.; Toya, Y.; Suzuki, H.; Matsumoto, T. The clinicopathological and molecular features of sporadic gastric foveolar type neoplasia. Virchows Arch. 2020, 477, 835-844. [CrossRef]

110. Abraham, S.C.; Park, S.J.; Lee, J.H.; Mugartegui, L.; Wu, T.T. Genetic alterations in gastric adenomas of intestinal and foveolar phenotypes. Mod. Pathol. 2003, 16, 786-795. [CrossRef] [PubMed]

111. Lim, C.H.; Cho, Y.K.; Kim, S.W.; Choi, M.G.; Rhee, J.K.; Chung, Y.J.; Lee, S.H.; Kim, T.M. The chronological sequence of somatic mutations in early gastric carcinogenesis inferred from multiregion sequencing of gastric adenomas. Oncotarget 2016, 7 , 39758-39767. [CrossRef] 
112. Pennelli, G.; Grillo, F.; Galuppini, F.; Ingravallo, G.; Pilozzi, E.; Rugge, M.; Fiocca, R.; Fassan, M.; Mastracci, L. Gastritis: Update on etiological features and histological practical approach. Pathologica 2020, 112, 153-165. [CrossRef]

113. Matsubara, A.; Sekine, S.; Kushima, R.; Ogawa, R.; Taniguchi, H.; Tsuda, H.; Kanai, Y. Frequent GNAS and KRAS mutations in pyloric gland adenoma of the stomach and duodenum. J. Pathol. 2013, 229, 579-587. [CrossRef]

114. Hashimoto, T.; Ogawa, R.; Matsubara, A.; Taniguchi, H.; Sugano, K.; Ushiama, M.; Yoshida, T.; Kanai, Y.; Sekine, S. Familial adenomatous polyposis-associated and sporadic pyloric gland adenomas of the upper gastrointestinal tract share common genetic features. Histopathology 2015, 67, 689-698. [CrossRef] [PubMed]

115. Lee, S.Y.; Saito, T.; Mitomi, H.; Hidaka, Y.; Murakami, T.; Nomura, R.; Watanabe, S.; Yao, T. Mutation spectrum in the Wnt/betacatenin signaling pathway in gastric fundic gland-associated neoplasms/polyps. Virchows Arch. 2015, 467, 27-38. [CrossRef] [PubMed]

116. Carneiro, F. Hereditary gastric cancer. Pathologe 2012, 33 (Suppl. S2), 231-234. [CrossRef]

117. Luo, W.; Fedda, F.; Lynch, P.; Tan, D. CDH1 gene and hereditary diffuse gastric cancer syndrome: Molecular and histological alterations and implications for diagnosis and treatment. Front. Pharmacol. 2018, 9, 1421. [CrossRef] [PubMed]

118. Corso, G.; Pedrazzani, C.; Pinheiro, H.; Fernandes, E.; Marrelli, D.; Rinnovati, A.; Pascale, V.; Seruca, R.; Oliveira, C.; Roviello, F. E-cadherin genetic screening and clinico-pathologic characteristics of early onset gastric cancer. Eur. J. Cancer 2011, 47, 631-639. [CrossRef]

119. Hansford, S.; Kaurah, P.; Li-Chang, H.; Woo, M.; Senz, J.; Pinheiro, H.; Schrader, K.A.; Schaeffer, D.F.; Shumansky, K.; Zogopoulos, G.; et al. Hereditary diffuse gastric cancer syndrome: CDH1 mutations and beyond. JAMA Oncol. 2015, 1, 23-32. [CrossRef]

120. Guilford, P.; Humar, B.; Blair, V. Hereditary diffuse gastric cancer: Translation of CDH1 germline mutations into clinical practice. Gastric Cancer 2010, 13, 1-10. [CrossRef]

121. Te Paske, I.B.A.W.; Garcia-Pelaez, J.; Sommer, A.K.; Matalonga, L.; Starzynska, T.; Jakubowska, A.; Solve-RD-GENTURIS Group; van der Post, R.S.; Lubinski, J.; Oliveira, C.; et al. A mosaic PIK3CA variant in a young adult with diffuse gastric cancer: Case report. Eur. J. Hum. Genet. 2021, 29, 1354-1358. [CrossRef]

122. Van der Post, R.S.; Vogelaar, I.P.; Manders, P.; van der Kolk, L.E.; Cats, A.; van Hest, L.P.; Sijmons, R.; Aalfs, C.M.; Ausems, M.G.; Gómez García, E.B.; et al. Accuracy of hereditary diffuse gastric cancer testing criteria and outcomes in patients with a germline mutation in CDH1. Gastroenterology 2015, 149, 897-906.e19. [CrossRef] [PubMed]

123. Carneiro, F.; Huntsman, D.G.; Smyrk, T.C.; Owen, D.A.; Seruca, R.; Pharoah, P.; Caldas, C.; Sobrinho-Simões, M. Model of the early development of diffuse gastric cancer in E-cadherin mutation carriers and its implications for patient screening. J. Pathol. 2004, 203, 681-687. [CrossRef]

124. Milne, A.N.; Sitarz, R.; Carvalho, R.; Carneiro, F.; Offerhaus, G.J. Early onset gastric cancer: On the road to unraveling gastric carcinogenesis. Curr. Mol. Med. 2007, 7, 15-28. [CrossRef]

125. Barber, M.; Murrell, A.; Ito, Y.; Maia, A.T.; Hyland, S.; Oliveira, C.; Save, V.; Carneiro, F.; Paterson, A.L.; Grehan, N.; et al. Mechanisms and sequelae of E-cadherin silencing in hereditary diffuse gastric cancer. J. Pathol. 2008, 216, 295-306. [CrossRef]

126. Grady, W.M.; Willis, J.; Guilford, P.J.; Dunbier, A.K.; Toro, T.T.; Lynch, H.; Wiesner, G.; Ferguson, K.; Eng, C.; Park, J.G.; et al. Methylation of the CDH1 promoter as the second genetic hit in hereditary diffuse gastric cancer. Nat. Genet. 2000, $26,16-17$. [CrossRef] [PubMed]

127. Oliveira, C.; Sousa, S.; Pinheiro, H.; Karam, R.; Bordeira-Carriço, R.; Senz, J.; Kaurah, P.; Carvalho, J.; Pereira, R.; Gusmão, L.; et al. Quantification of epigenetic and genetic 2nd hits in CDH1 during hereditary diffuse gastric cancer syndrome progression. Gastroenterology 2009, 136, 2137-2148. [CrossRef]

128. Humar, B.; Fukuzawa, R.; Blair, V.; Dunbier, A.; More, H.; Charlton, A.; Yang, H.K.; Kim, W.H.; Reeve, A.E.; Martin, I.; et al. Destabilized adhesion in the gastric proliferative zone and c-Src kinase activation mark the development of early diffuse gastric cancer. Cancer Res. 2007, 67, 2480-2489. [CrossRef] [PubMed]

129. Garziera, M.; Canzonieri, V.; Cannizzaro, R.; Geremia, S.; Caggiari, L.; De Zorzi, M.; Maiero, S.; Orzes, E.; Perin, T.; Zanussi, S.; et al. Identification and characterization of $\mathrm{CDH} 1$ germline variants in sporadic gastric cancer patients and in individuals at risk of gastric cancer. PLoS ONE 2013, 8, e77035.

130. Group HaCC. Gastric cancer and Helicobacter pylori: A combined analysis of 12 case control studies nested within prospective cohorts. Gut 2001, 49, 347-353. [CrossRef]

131. Huang, J.Q.; Sridhar, S.; Chen, Y.; Hunt, R.H. Meta-analysis of the relationship between Helicobacter pylori seropositivity and gastric cancer. Gastroenterology 1998, 114, 1169-1179. [CrossRef]

132. Chan, A.O.; Lam, S.K.; Wong, B.C.; Wong, W.M.; Yuen, M.F.; Yeung, Y.H.; Hui, W.M.; Rashid, A.; Kwong, Y.L. Promoter methylation of E-cadherin gene in gastric mucosa associated with Helicobacter pylori infection and in gastric cancer. Gut 2003, 52, 502-506. [CrossRef] [PubMed]

133. Chan, A.O.; Huang, C.; Hui, W.M.; Cho, C.H.; Yuen, M.F.; Lam, S.K.; Rashid, A.; Wong, B.C. Stability of E-cadherin methylation status in gastric mucosa associated with histology changes. Aliment. Pharmacol. Ther. 2006, 24, 831-836. [CrossRef] [PubMed]

134. Lee, H.E.; Smyrk, T.C.; Zhang, L. Histologic and immunohistochemical differences between hereditary and sporadic diffuse gastric carcinoma. Hum. Pathol. 2018, 74, 64-72. [CrossRef] [PubMed] 
135. Uemura, N.; Okamoto, S.; Yamamoto, S.; Matsumura, N.; Yamaguchi, S.; Yamakido, M.; Taniyama, K.; Sasaki, N.; Schlemper, R.J. Helicobacter pylori infection and the development of gastric cancer. N. Engl. J. Med. 2001, 345, 784-789. [CrossRef] [PubMed]

136. Yun, C.Y.; Kim, N.; Lee, J.; Lee, J.Y.; Hwang, Y.J.; Lee, H.S.; Yoon, H.; Shin, C.M.; Park, Y.S.; Kim, J.W.; et al. Usefulness of OLGA and OLGIM system not only for intestinal type but also for diffuse type of gastric cancer, and no interaction among the gastric cancer risk factors. Helicobacter 2018, 23, e12542. [CrossRef] [PubMed] 